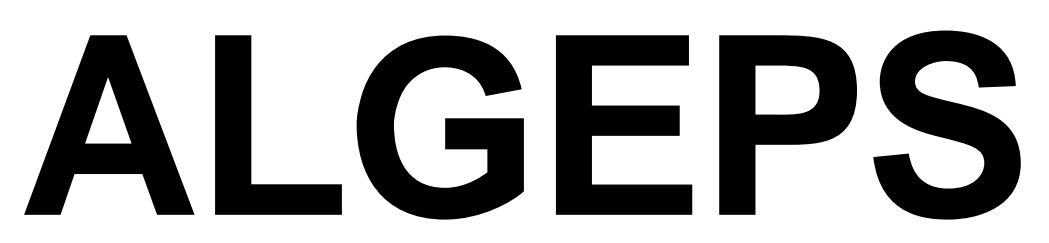

REVISTA DE GEOLOGIA, SÈRIE B n 604 - Octubre del 2012

ISSN $1132-7014$

D.L.B. 28.178 - 92

13 pàgines

RECORREGUT DE RECERCA GEOLÒGICA, MINERA I MINERALÒGICA PER LA COMARCA DE L'ALTA SEGARRA CALAFINA (ANOIA): DES DE SANT MARTÍ DE SESGUEIOLES A CALAF; I DES DE DURFORT A CASTELLFOLLIT DE RIUBREGÓS

Josep M. Mata-Perelló i Joaquim Sanz Balagué

Aquest recorregut va ésser experimentat amb docents el dia 20 DE FEBRER DEL 2011 


\section{RECORREGUT DE RECERCA GEOLÒGICA, MINERA I MINERALÒGICA PER LA COMARCA DE L'ALTA SEGARRA CALAFINA (ANOIA): DES DE SANT MARTÍ DE SESGUEIOLES A CALAF; I DES DE DURFORT A CASTELLFOLLIT DE RIUBREGÓS / 20 DE FEBRER DEL 2011}

Per Josep M. MATA-PERELLÓ i Joaquim SANZ i BALAGUÉ

\section{ADVERTIMENTS PREVIS}

Com en altres recorreguts de RECERCA GEOLÒGICA I MINERALÒGICA ..., si es disposa del temps suficient, poden efectuar-se passant per totes les parades i filloles. En cas contrari, recomanem prescindir de les anomenades PARADES - CONDICIONALS.

Com de costum, creiem oportú de recomanar, que alhora d'efectuar el recorregut de l'itinerari es cerqui la informació més àmplia possible sobre l'estat dels trams del recorregut a realitzar, tant per pistes forestals, com per carreteres en mal estat de conservació. En aquest itinerari, hi ha alguns trams que s'efectuaràn totalment per camins de terra. Així, entre aquests, cal fer esment del que s'efectuarà entre Sant Martí de Sesgueioles i les mines de lignit, entre altres recorreguts. També, el recorregut que es farà per arribar a les Mines de Lignit de Durfort o el de les explotacions de calcolutites de Can Solé (Calonge de Segarra).

També, per altra banda, qualsevol cas, $i$ en tot moment, recomanem tenir el màxim respecte per al Medi Natural que ens envolta.

\section{BREU INTRODUCCIÓ}

En aquesta ocasió, el recorregut del present itinerari discorrerà íntegrament per la Depressió Geològica de l'Ebre, una sola de les tres unitats geològiques que constitueixen Catalunya. Per d'altra banda, dintre d'aquesta, ho farà exclusivament per un dels sectors que la constitueixen (MATA-PERELLÓ, 1985): exactament per la seva Depressió Central.

Tot i així, ho farà pels indrets centrals d'aquesta, on es troba replegada per les alineacions pirinenques i diapíriques que la creuen d'Est a Oest. Concretament pels indrets on aquestes alineacions es corresponen a el relleu, donant lloc a una sèrie d'estribacions com la Serra de Castelltallat (per la qual es circularà tangencialment en els trams centrals del recorregut de l’itinerari, entre Calonge de Segarra i Castellfollit de Riubregós).

Així, el recorregut començarà per les immediacions de la localitat de Sant Martí de 
Sesgueioles, des d'on es traslladarà cap a Calaf. Després, es dirigirà cap a Calonge de Segarra, creuant després l'eix de l'Anticlinal de Súria. A continuació el recorregut es dirigirà cap a Castellfollit de Riubregós, per Finalment, per on finalitzarà

Per d'altra banda, el recorregut de l'itinerari es desenvoluparà per una de lescomarques de la Catalunya Central; per la de l’Alta Segarra Calafina (Anoia).

\section{OBJECTIUS GENERALS}

A través d'aquest itinerari de recorregut eminentment geològic, s'intentaran d'aconseguir els següents objectius:

1.- Observació dels materials cenozoics que reblen Depressió Geològica de l’Ebre (i més exactament de la seva Depressió Central), al llarg i ample dels indrets per on discorrerà el recorregut d'aquest itinerari. Aquests materials formen part de les següents unitats litoestratigràfiques: Formació Barbastre, Formació Súria, Complex de Sanaüja i Formació Tàrrega. Tots aquests materials els anirem trobant a diferents indrets del recorregut de l'itinerari.

2.- Estudi de l'estructura de la Depressió Central, pels diferents indrets per on discorrerà l'itinerari; així com els diversos accidents que anirem trobant al llarg del recorregut. Així, ens centrarem en l'observació del Sinclinal de Calaf, i en especial de l'Anticlinal de Súria. El primer el trobarem prop de Calaf; mentre que el segon el tallarem entre Calonge de Segarra i Castellfollit de Riubregós.

3.- Observació de la Serra de Castelltallat, desenvolupada sobre l'Anticlinal de Súria, pels indrets en els quals el recorregut transitarà per la seva marge occidental, pels voltants de Calonge de Segarra.

4.- Observació de les explotacions les diferents explotacions (antigues i actuals), que trobarem al llarg del recorregut, com:

4A) de les antigues explotacions lignitíferes, intercalades entre els materials de la Formació Tàrrega. Totes elles situades prop de les localitats de Calaf i Durfort, a l'Alta Segarra Calafina (Anoia).

4B) de les explotacions de calcolutítiques dutes a terme entre Calaf, Durfort i Castellfollit de Riubregós. Es situen intercalades entre els materials de la Formació Tàrrega els materials anteriors

5.- Observació dels impactes produïts sobre el Medi Natural, per les explotacions mineres anteriorment esmentades.

6.- Observació, si śescau, de les manifestacions radioactives, originades per la presència de complexes d'uranil, entre els materials carbonosos, prop de Durfort.

7.- Observació de diferents mineralitzacions secundàries, originades a partir de l'alteració de pirites primàries incloses entre els lignits, amb la formació de guixos secundaris, d'oxids de ferro i de sulfats d'aquest mateix metall. 
8.- Observació de diferents indrets relacionats amb el Patrimoni Geològic i Miner, que anirem trobant al llarg del recorregut.

\section{ANTECEDENTS}

Existeix un antecedent bibliogràfic, en relació al recorregut d'aquest itinerari. Es tracta de MATA-PERELLÓ et altre (2000). També hi ha diverses descripcions relatives a trams parcials del mateix en els treballs de diversos autors, com: MASACHS et altri (1981), en MATA-PERELLÓ (1995, 1996, 1997, 1999a, 1999b, 2005, 2007a, 2007b i 2010). Moltes d'elles coincideixen en alguns trams amb el que ara presentem, en especial els dos darrers.

Per d'altra banda, i pel que fa a les mineralitzacions existents, tant a la comarca del Bages, com a la d'Anoía, ens remetem a uns altres treballs nostres; es tracta de: MATAPERELLÓ (1990 i 1991), i a MATA-PERELLÓ i COLLDEFORNS (1993). aquest darrer fa referència a l'inventari de les mineralitzacions situades a la comarca de l'Alta Segarra.

I finalment, pel que correspon als treballs geològics de caràcter general, ens hem de referir necessàriament a les publicacions de: COLLDEFORNS (1986), GUIMERÀ et altri (1992), i RIBA et altri (1976); Així com els treballs de l’ITGME (1975 i 1982).

Tots aquests treballs acabats d'esmentar, figuren relacionats per ordre alfabètic a l'apartat de REFERÈNCIES BIBIOGRAFIQUES.

\section{RECORREGUT DE L'ITINERARI}

El recorregut del present itinerari, s'inicia a la localitat de Sant Martí de Sesgueioles, on es realitzarà la primera aturada. Després, el recorregut es dirigirà cap a Calaf, i cap a Durfort, per tal de fer una fillola i una breu aturada.

Tot seguit, el recorregut retornarà fins prop de Calaf, per tal de continuar per la carretera C-1412, amb la intenció d'arribar fins a Castellfollit de Riubregós. En aquest recorregut s'efectuaran diverses aturades. Finalitzant aquí el recorredgut, tot anan cap a Ivorra (Segarra).

\section{DESCRIPCIÓ DE L'ITINERARI}

Com ja es habitual, s'estructurarà en una sèrie d'estacions (parades o aturades), en les qual es faran descripcions geològiques o mineralògiques, segons s'escaigui. En cada parada s'indicarà el número del mapa topogràfic a escala 1:50.000 on es troba l'indret. Per això, śutilitzarà la cartografia editada per l'"Instituto Geográfico y Catastral de España".

En aquest cas, el recorregut de l'itinerari passarà per part dels dos següents fulls: $\mathbf{3 6 1}$ (o de Guissona) i 362 (dit de Calaf). També farem servir el mapa de la comarca del Bages, editat 
per l'Institut Cartogràfic de Catalunya, a escala 1:50.000.

Així doncs, la relació general i ordenada, de les aturades que composen el recorregut d'aquest itinerari, és la següent:

PARADA 1. MINA A "CEL OBERT" DE LA GUARDIA (la Guàrdia Pilosa, del terme de Pujalt, comarca d'Anoia, subcomarca de l'Alta Segarra). (Full 362).

El recorregut d'aquest itinerari, cal iniciar-lo a la població de Sant Martí de Sesgueioles, des d'on ens caldrà agafar el camí que es dirigeix cap a la Guàrdia Pilosa. Abans de començar la pujada es trobarà una antiga explotació lignitífera a cel obert. Aquí farem la present aturada, després de recórrer uns 1’5 Km des de la població esmentada inicialment.

En aquest recorregut hem anat trobant afloraments dels materials calcolutítics (a filades més carbonatades, i d'altres més sorrenques) de la Formació Tàrrega. Es de destacar que sovint es fan força palesos els típics relieves en cuesta en tot aquest trajecte, a la bora dreta del mateix.

En aquest indret hi ha una antiga explotació dels lignits. aquesta explotació es va realitzar a cel obert, tot i la poca potència dels nivells lignitífers (amb un màxim de $20 \mathrm{~cm}$, normalment). Aquesta explotació va produir un greu atemptat contra el Medi Natural. A l'actualitat s'està intentant paliar aquest desgavell.

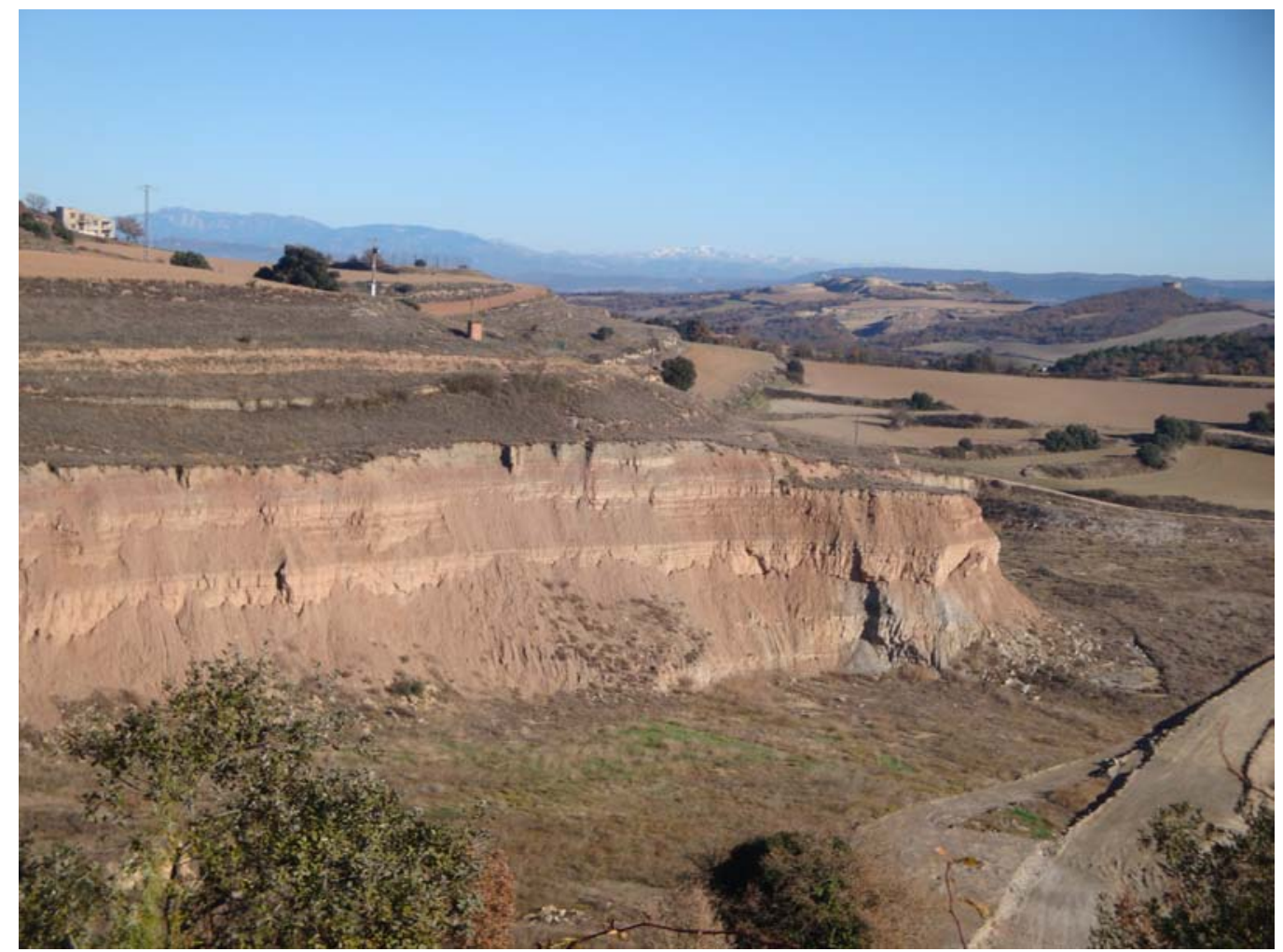

\section{FOPTOGRAFÍA 1. ANTIGA EXPLOTACIÓ, PER SOTA DE LA GUÀRDIA PILOSA}

Així, cal fer un especial esment, en l'aspecte geo-ambiental, doncs les explotacions lignitíferes anteriors van provocar, en el seu temps, una gran destrossa ecològica, de la qual la 
zona no es troba encara restaurada, en la seva integritat, amb profundes cicatrius sense reblir. També, per d'altra banda, al nostre entendre, va haver-hi uns errors greus alhora de realitzar l'explotació a "cel obert", ja que els nivells de lignit eren massa profunds, i calia explotar-los subterràniament.

Entre els lignits de la Formació Tàrrega, es troben abundants mineralitzacions ferruginoses, amb la presència de: MARCASSITA, MELNIKOWITA i PIRITA (el més abundant dels tres), com a minerals primaris. I també amb la presència d'abundants alteracions com: GOETHITA (limonítica), HEMATITES, FERROHEXAHIDRITA, MELANTERITA (el més abundant d'aquest grup), i SIDEROTIL. També es troben altres minerals, com la CALCITA i el GUIX.

En aquest indret, també es pot observar la problemàtica actual, en situar a la pedrera un abocador de runes (dintre del terme de Sant Martí de Sesgueioles, però per sota de la població de la Guàrdia Pilosa).

PARADA 2. EXPLOTACIONS DE CALCOLUTITES DEL TURÓ DE SANT SEBASTIÀ, (terme municipal de Calaf, comarca d'Anoia, subcomarca de l'Alta Segarra). (Full 362).

Des de la parada anterior, cal continuar cap al Nord, per tal d'arribar al poble de Calaf, la capital de la subcomarca. En arribar-hi, cal adreçar-se cap a les properes explotacions de calcolutites. En aquest indret, prop de les explotacions, i després de recórrer uns $4 \mathrm{Km}$, és on ens caldrà fer la present aturada.

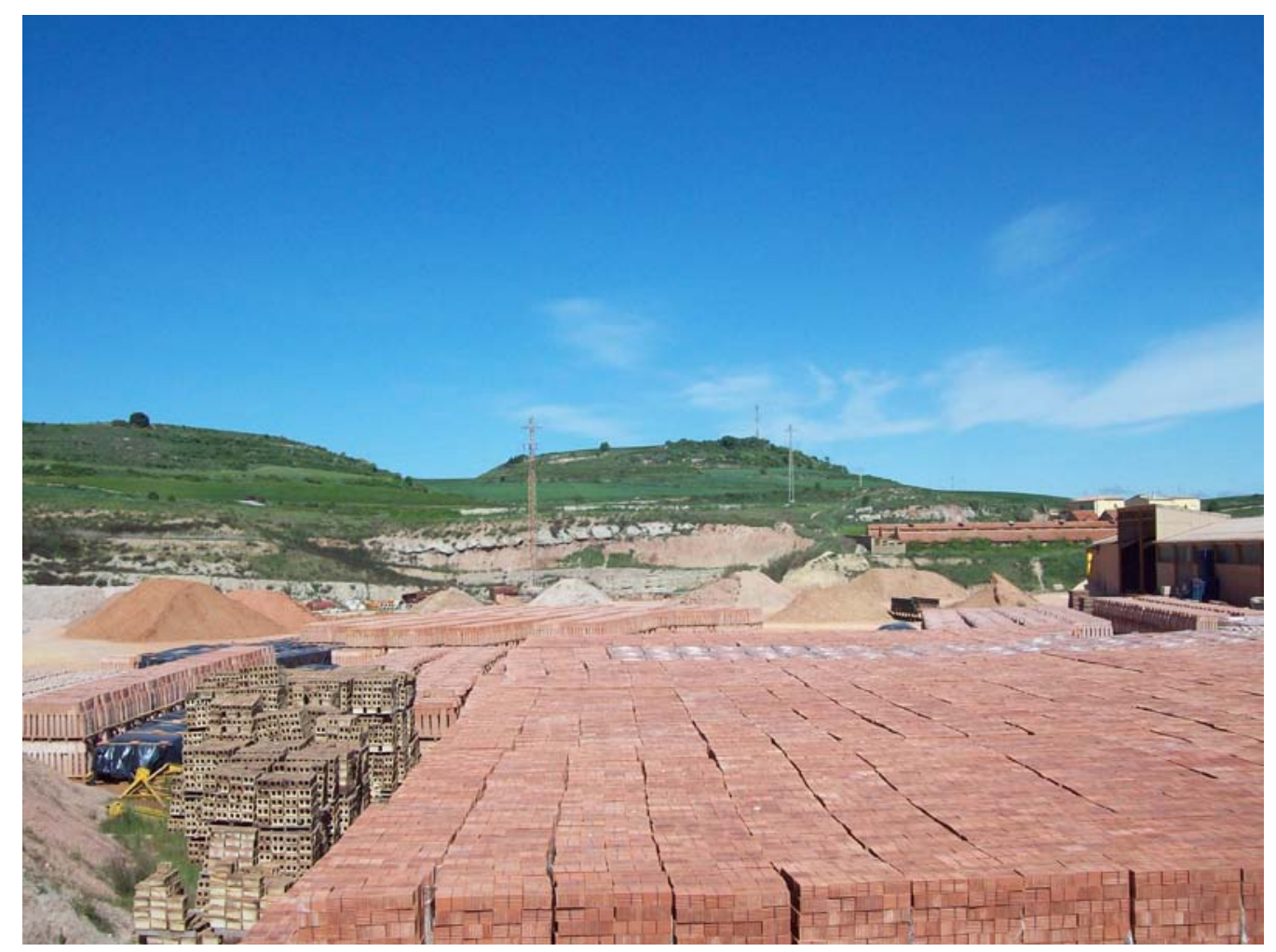


En aquest recorregut, hem anat tallant els materials calcolutítics ja esmentats a la parada anterior. I, precisament en aquest lloc, aquests es troben en explotació, per tal d'ésser utilitzats en la fabricació de totxos i de ceràmica.

Pel que fa a l'explotació, cal dir que es força gran, i els materials extrets es porten cap a la propera fàbrica, situada a la bora de Calaf. Finalment, cal dir que per accedir a l'explotació, cal tenir necessàriament l'autorització de l'empresa (Ceràmiques Calaf S.A.).

Per d’altra banda, en aquest recorregut, ben prop de Calaf, haurem trobat una explotació de calcolutites.

PARADA 3. VISIÓ GENERAL DE L'ANTIGA, I DE L“ACTUAL ZONA MINERA DE DURFORT (Durfort, pertany al terme de Calonge de Segarra, comarca d'Anoia, subcomarca de l'Alta Segarra). (Full 362).

Des de la parada anterior, caldrà sobrepassar la població de Calaf. A la mateixa sortida de la població, cal agafar el camí que s’adreça a les antigues explotacions de lignit de Durfort, situades a menys de $1 \mathrm{Km}$ de Calaf. Nosaltres, aquesta aturada la realitzarem poc abans de creuar l’Eix Transversal, a uns $5 \mathrm{Km}$ de la parada anterior.

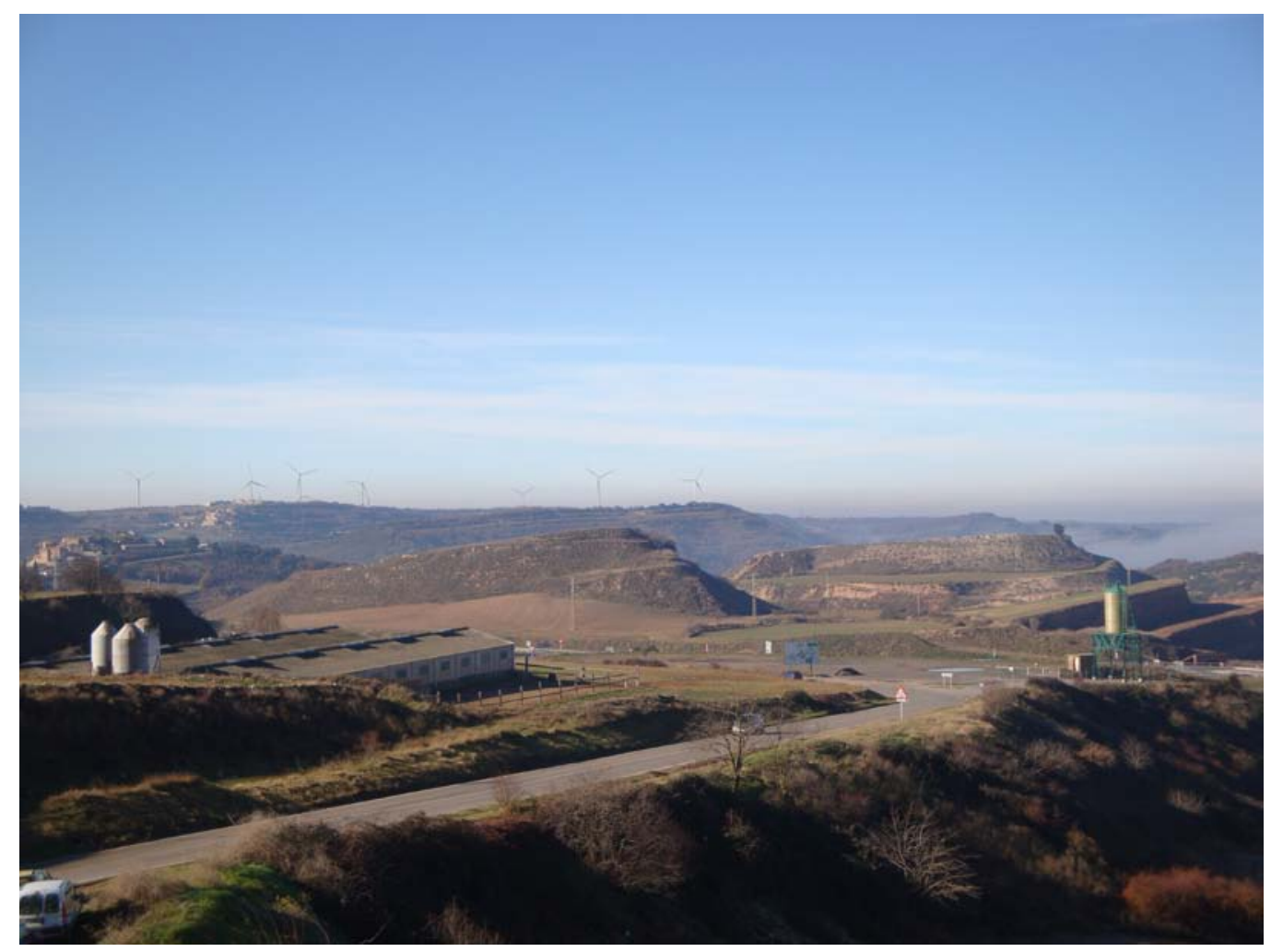

FOTOGRAFÍA 3. “RELIEVES EN CUESTA” PROP DE DURFORT

En aquest indret, i seguint el camí, es troba un gran nombre d'antigues explotacions lignitíferes sotsterrànies totalment enrunades. Per d'altra banda, també es troben moltes explotacions actuals de nivells calcolutítics, adreçats a servir de matèria prima a les properes 
ceràmiques de Durot. Unes i altres explotacions, es troben ubicades als afloraments de la Formació Tàrrega, per on anem circulant des d'un principi del recorregut de l'itinerari, a Sant Martí de Sesgueioles.

Per d'altra banda, des d'aquest indret es pot veure el lloc on hi havia l'antiga explotació de lignit d'Aleny. Aquesta explotació es va realitzar a “cel obert”. A l'actualitat es pot veure un camp de cereals a l'indret de l'explotació.

Des d'aquest lloc, mirant cap a Durfort i cap a Mirambell (cap a ponent, fonamentalment), es poden veure els relleus cenozoics, tot formant un interessant "relieve en cuesta" (FOTOGRAFIA 3).

PARADA 4. MINES DE LIGNIT DE DURFORT; DEL CAMÍ A CALONGE (Durfort, pertany al terme de Calonge de Segarra, comarca d'Anoia, subcomarca de l'Alta Segarra). (Full 362).

Des de la parada anterior, cal continuar per la carretera C - 1412 - B. I ens caldrà anar cap on hi ha l'indret on es troba l'Ajuntament de Calonge de Segarra, a Durfort. Aquí ens caldrà seguir pel camí de terra que sén va cap a Calonge de Segarra. Poc després de deixar Durfort (a uns 200 metres), per la dreta trobarem un camí que baixa cap a la vall. Ens caldrà agafar-lo, i en uns 400 metres arribarem a unes antigues mines, on farem una nova aturada, a menys de $3 \mathrm{Km}$ de l'anterior.

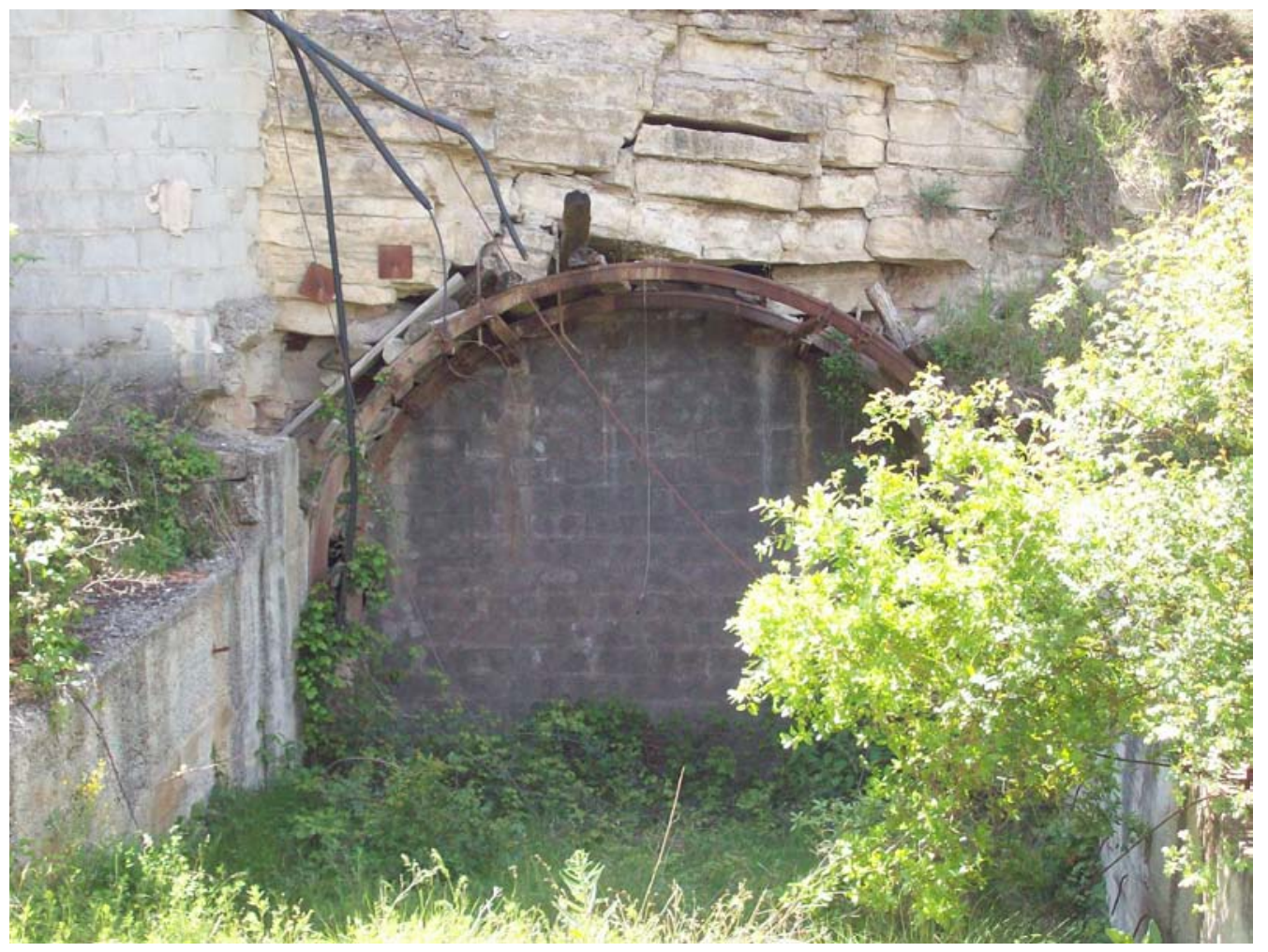

\section{FOTOGRAFÍA 4. UNA DE LES BOCAMINES. MINES DE LIGNIT DE DURFORT}

En aquest recorregut, hem anat trobant els materials esmentats a les darreres aturades anteriorment realitzades. És a dir: els materials de la Formació Tàrrega, entre els quals es 
troben els lignits que s’han explotat a diferents indrets, com on ara som.

Aquí va haver-hi una de les darreres explotacions, per mineria subterrània, de la comarca. Es tracta d'un bon indret per observar com es feien aquestes explotacions i com es fortificaven les mines, amb entibacions i quadres metal-lics. També es pot observar com es subjectava el terreny, per tal d'evitar despreniments (tot i que les mines es troben tencades i segellades les entrades).

PARADA 5. CASTELL DE CALONGE DE SEGARRA, (Calonge de Segarra, terme municipal de Calonge de Segarra, comarca d'Anoia, subcomarca de l'Alta Segarra). (Full 362).

Després de fer la parada anterior, cal retornar fins al camí - carreter que des de Durfort es dirigeix cap a Calonge de Segarra (en realitat cap om hi ha l'esglèsia algunes cases escampades). En arribar a aquest indret farem una nova aturada, a uns $2 \mathrm{Km}$ de l'anterior.

En aquest recorregut, hem anat trobant els mateixos materials ja esmentats a les parades anteriors. Precisament, aquests són els materials que afloren a l'indret on farem la present aturada, per sota del turó del Castell.

En aquest indret es pot veure com els anteriors materials formen el flanc d'un anticlinal. Es tracta de l'Anticlinal de Súria, que des d'aquesta població fins aquí, dona lloc a la Serra de Castelltallat.

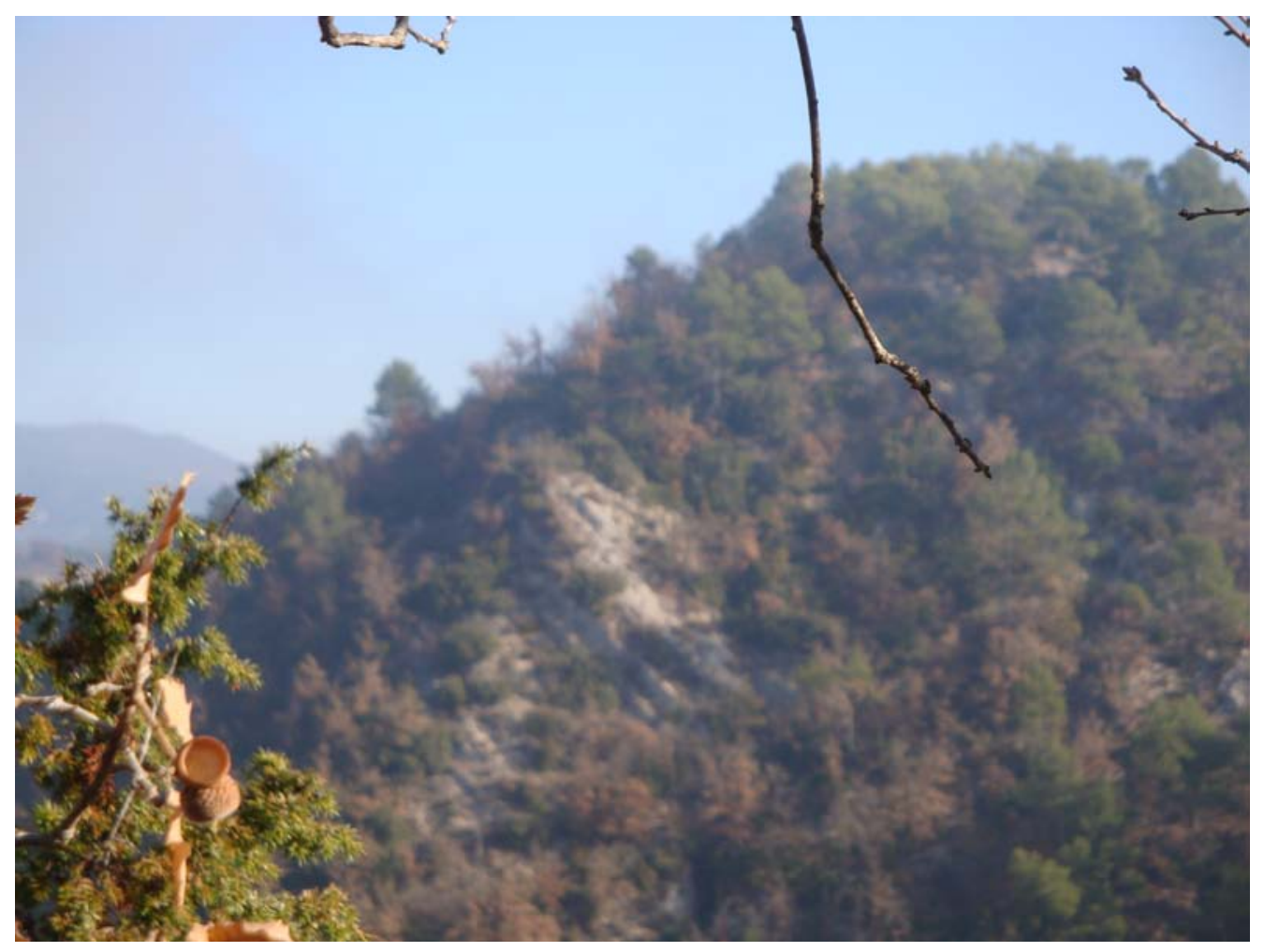

FOTOGRAFIA 5. UN ASPECTE DEL FLANC MERIDIONAL DEL ANTICLINAL DE SÚRIA 
PARADA 6. PEDRERES DEL SOLÉ, (el Solé, terme municipal de Calonge de Segarra, comarca d'Anoia, subcomarca de l’Alta Segarra). (Full 362).

Després de fer la parada anterior, cal retornar fins al camí - carreter que des de Durfort es dirigeix cap a Calonge de Segarra (en realitat cap om hi ha l'esglèsia algunes cases escampades). Després, ens caldrà baixar cap a la carretera comarcal C-1412 - B, la qual enllaça Calaf amb Castellfollit de Riubregós. En arribar a la carretera, anirem momentàniament cap a Calaf (uns 100 métres), fins trobar el camí que es dirigeix cap a les pedreres del Solé, per on farem una nova aturada, a uns $3 \mathrm{Km}$ i escaig de la parada anterior. Aquesta aturada la farem a unes antigues explotacions situades a l'esquerra de la carretera comarcal, a ponent de la mateixa, a menys de $1 \mathrm{Km}$.

En aquest recorregut, hem anat trobant els mateixos materials ja esmentats a les parades anteriors. Precisament, aquests són els materials que afloren a l'indret on farem la present aturada, on han estat explotats. Aquí hi havia una antiga explotació de calcolutites. Aquestes havien d'estar emprades per a la fabricació de ciment ràpid. A l'actualitat es pot veure be l'explotació; així com alguns dels antics edificis. També cal dir que aquestes explotacions són les úniques que existeixen a la zona. Precissament, prop de la carretera C - 1412 - B amb la que procedeix de Calonge de Segarra (per on hem vingut) n'hi ha unes altres.

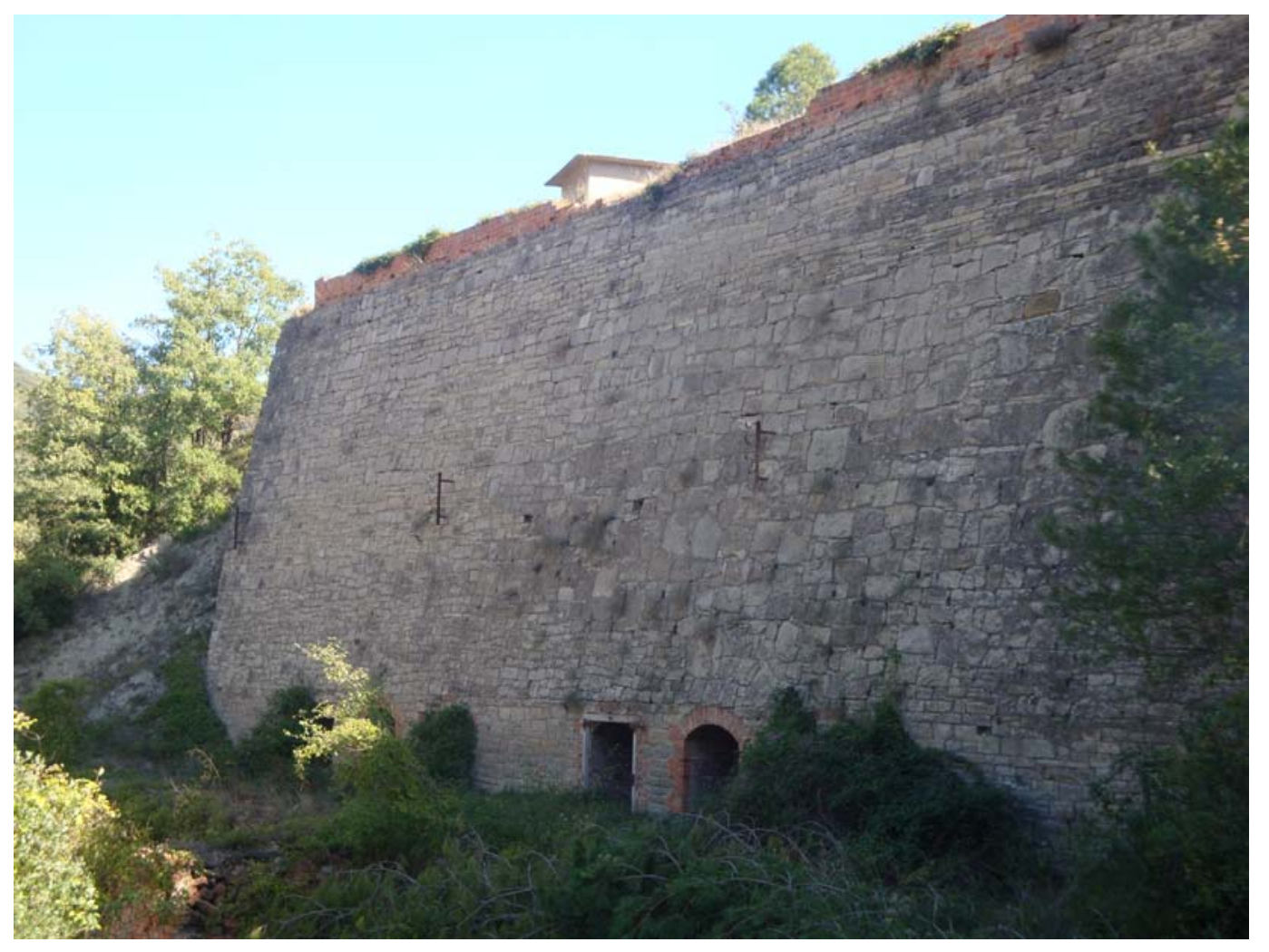

FOTOGRAFIA 6. TOLVES I FORNS DE LA PEDRERA DE CAN SOLÉ

PARADA 7. PEDRERES DE CASTELLFOLLIT DE RIUBREGÓS, (terme municipal de Castellfollit de Riubregós, comarca d'Anoia, subcomarca de l'Alta Segarra). (Full 362).

Després de fer l'aturada anterior, cal seguir cap al NW. Aviat es deixaran enrera els 
trencalls de Calonge de Segarra i Molsosa., Finalment s'arribarà a les immediacions del poble de Castellfollit de Riubregós. Abans d'arribar-hi, però, farem una nova aturada, a la dreta de la carretera.

En aquest recorregut, hem continuat trobant els mateixos materials ja esmentats a les parades anteriors. Al respecte, cal dir que aquests són els materials que afloren a l'indret on farem la present aturada.

Com al cas anterior, aquí hi havia una antiga explotació de calcolutites. Aquestes havien d'estar emprades per a la fabricació de ciment ràpid. A l'actualitat es pot veure be l'explotació; així com molts dels antics edificis.

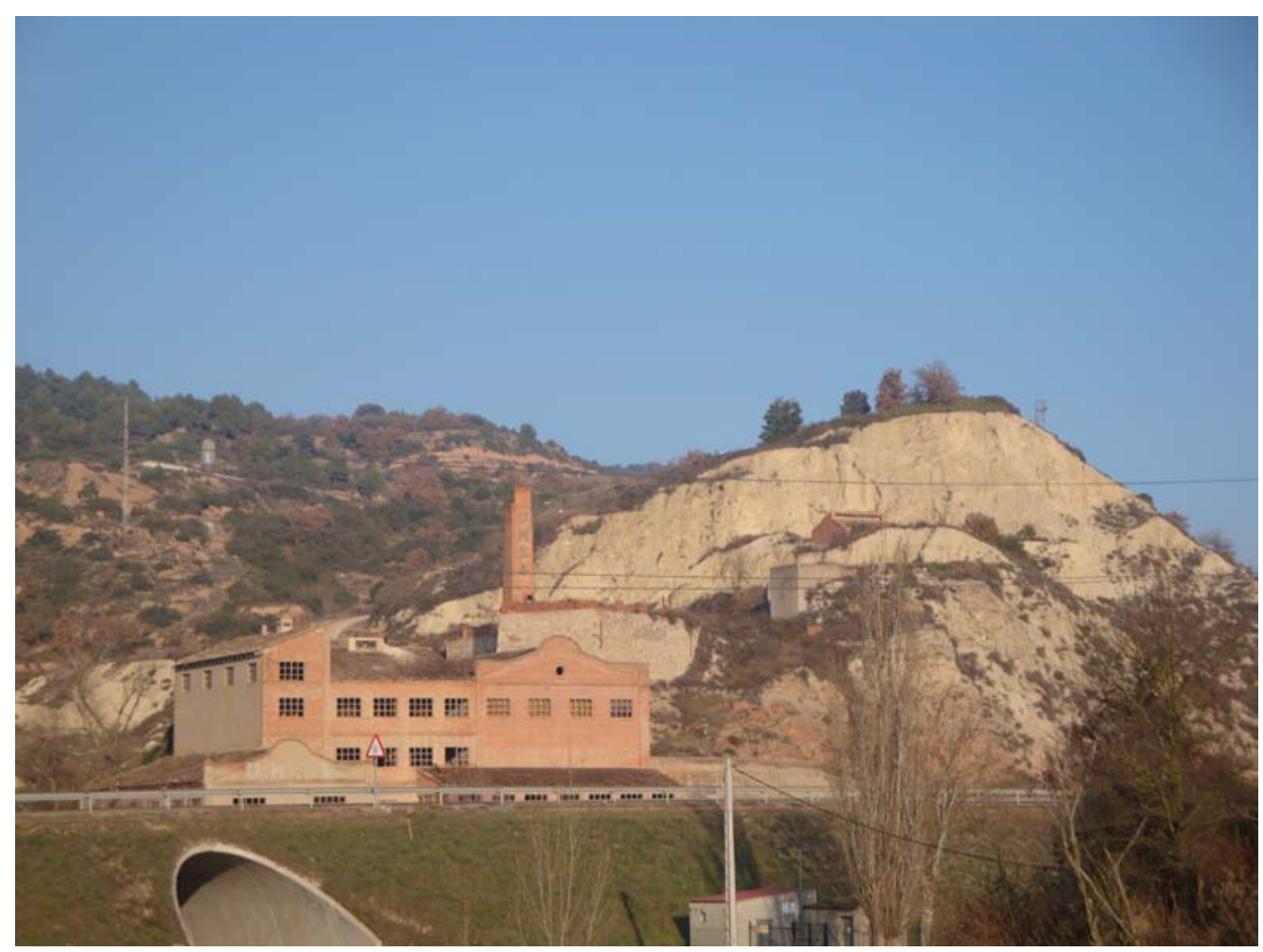

FOTOGRAFIA 7. UN ASPECTE D’UNA DE LES PEDRERES

\section{PARADA 8. INMEDIACIONS DEL PONT SOBRE EL RIU LLOBREGÓS, (terme municipal de Castellfollit de Riubregós, comarca d'Anoia, subcomarca de l’Alta Segarra). (Full 362).}

Des de la parada anterior cal passar a l'altra banda del riu, cap al poble de Castellfollit de Riubregós, després de retornar de nou a la carretera comarcal C-1412. En arribar a la darrera població esmentada, caldrà fer la present aturada, després de recórrer uns 0 ×8 Km.

En aquest recorregut, s'anirà transitant per entre els materials guixosos esmentats a la parada anterior. Tot i així, prop de Castellfollit es fan clarament palesos els nivells calcolutítics del Complex Lacustre de Sanaüja. Des d'aquest indret es fan clarament paleses diverses explotacions abandonades dels materials calcolutítics acabats d'esmentar. També es fa palès 
l’aflorament dels guixos per sota del castell.

Aquests materials configuren en conjunt l'Anticlinal de Sanaüja, amb els guixos de la Formació Barbastre al nucli, i les calcolutites als flancs. Aquest anticlinal es pot anar seguint fins Artesa de Segre, Cubells i Camarasa.

\section{EN AQUEST INDRET FINALITZA L'ITINERARI}

\section{REFERÈNCIES BIBLIOGRÂFIQUES}

COLLDEFORNS, B. (1986).- Estudi geològic del Bages, Inèdit, 385 pàgines. Sant Vicenç de Castellet.

GUIMERÀ, J. et altri (1992).- Geologia (II), Història Natural dels Països Catalans, Vol. 2, 547 pag. Enciclopèdia catalana, S.A., Barcelona

IGME (1975).- Mapa Geológico de España a Escala 1:50.000 (2a Sèrie). Full i Memòria $\mathrm{n}^{\mathrm{o}} \underline{330}$ (Cardona). Inst. Tecnológico y GeoMinero de España. Minist. Indus. Ener. Madrid

IGME (1982).- Mapa Geológico de España a Escala 1:50.000 (2a Sèrie). Full i Memòria $n^{0} \underline{362}$ (Calaf). Inst. Tecnológico y GeoMinero de España. Minist. Indus. Ener. Madrid

MASACHS, V. et altri (1981).- Itineraris geològics per Anoia, Bages, Berguedà i Solsonès. Pub. Caixa d'Estalvis de Manresa, 205 pag. Manresa

MATA-PERELLÓ, J.M. (1984).- Depressió Central o Depressió de l’Ebre, Revista Dovella, $n^{0}$ 36, pp 85-89. Manresa

MATA-PERELLÓ, J.M. (1990).- Inventari Mineralògic de la comarca d'Anoía. Revista Xaragall, $\mathrm{n}^{\circ}$ 24, 40 pàgines. Manresa

MATA-PERELLÓ, J.M. (1991).- Els Minerals de Catalunya. Arxius de la Secció de Ciències, t. XCIII. Institut d'Estudis Catalans. Barcelona

MATA-PERELLÓ, J.M. (1995).- Recerca geològica i mineralògica per l'Alta Segarra i pel Bages: des de Sant Martí de Sesgueioles a Súria. Xaragall, sèrie $B, \mathrm{n}^{\circ}$ 2, 17 pàg. Manresa

MATA-PERELLÓ, J.M. (199).- Recerca geològica i mineralògica per l’Anoia, la Segarra i el Solsonès: de Calaf a la Molsosa i a Torà. Algeps, sèrie $B, \mathrm{n}^{\circ}$ 9, 11 pàg. Manresa

MATA-PERELLÓ, J.M. (1997).- Recorregut de recerca geològica i mineralògica per la Segarra i per l'Alta Segarra (Anoia): des de Sant Martí de Sesgueioles a Calaf i a Torà de Riubregós. Inèdit, 17 pàgines. Manresa 
MATA-PERELLÓ, J.M. (1999a).- Recerca geològica per les comarques del Bages i de l'Anoia: des de Castellfollit de Riubregós a Rajadell i a Calaf. Algeps, sèrie $B, \mathrm{n}^{\circ} 118,11$ pàgines. Manresa

MATA-PERELLÓ, J.M. (1999b).- Recorregut de recerca geològica i mineralògica per les comarques del Bages, Alta Segarra i Anoia. Des de Rajadell a Calaf i a Ivorra, Inèdit. 14 pàg. Manresa

MATA-PERELLÓ, J.M. (2005).- Recerca geològica, minera i mineralògica per les comarques de l'Alta Segarra (Anoia) i de la Segarra: des de sant Martí de Sesgueioles a Calaf; i des de Durfort a Sant Ramon. Inèdit. 8 pag. Manresa

MATA-PERELLÓ, J.M. (2007a).- Recorregut de recerca geològica, minera i mineralògica per les comarques de l'Alta Segarra (Anoia) i de la Segarra: des de Sant Martí de Sesgueioles a Calaf; i des de Durfort a Castellfollit de Riubregós, Ivorra i a Sant Ramon. Inèdit. 8 pàgines. Manresa

MATA-PERELLÓ, J.M. (2007b).- Recorregut de recerca geològica, minera i mineralògica per les comarques de l'Anoia, l'Alta Segarra calafina (Anoia) i de la Segarra: des de la Panadella a Sant Martí de Sesgueioles, Calaf, Durfort i a Castellfollit de Riubregós. Inèdit. 10 pàgines. Manresa

MATA-PERELLÓ, J.M. (2010).- Recorregut de recerca geològica, minera i mineralògica per les comarques de l'Alta Segarra Calafina (Anoia) i de la Segarra: des de Sant Martí de Sesgueioles a Calaf; i de Durfort a Castellfollit de Riubregós, Torà de Riubregós i a Ivorra. Inèdit. 16 págines. Manresa

MATA-PERELLÓ, J.M. i COLLDEFORNS, B, (1993).- Inventari Mineralògic de la comarca del Bages, Xaragall, nº 23, 36 pàgines. Manresa

MATA-PERELLÓ, J.M.; MATA LLEONART, R. i ESPUNY SOLANÍ, J. (2000).Recerca geològica i de coneixement dels georrecursos per la comarca de l'Alta Segarra (Anoia) i de la Segarra: des de Sant Martí de Sesgueioles a Calonge de Segarra i a Ivorra. Inèdit. 10 pag. Manresa

RIBA ARDERIU, O. Et altri. (1976).- Geografia física dels Països Catalans. Edit Ketres. Barcelona 